\title{
GIFTS AND ACQUISITIONS
}

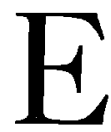

GG HARBOR CITY, along the Jersey shore, was founded exactly one hundred years ago, in I 855 . With the opening-up of that area by way of new rail facilities, promoters laid out the town and set about populating it. This was not the only such promotion in South Jersey; it was unusual, however, as a purely German settlement, and so conceived. In the I 850 's there was agitation against immigrants which developed political strength in the so-called Know-Nothing Party. Bewildered by the signs of hostility around them, Germans in Philadelphia, Baltimore, and elsewhere were persuaded to join with others in forming an exclusive community of their own national background. Many of the original plans of the colony were not to be realized, of course, and the ideal of a pure German population was one of these.

Early in the community's history, in I 859, a German newspaper was started, the Pilot. There were other short-lived papers, but the Pilot outlived them all, and lasted until the first World War. From Mr. A. H. Kroekel, son of the last editor, has been received a file of this unusual newspaper, which largely covers the first fifty years of Egg Harbor City, I 86I-I 9I 5. There is much to be learned from such sources as this, about the city itself, about various aspects of state history, and about the adaptation problems of immigrants. Indeed, the file of the Pilot came to the Library as a by-product of research on the history of Egg Harbor City. Particular thanks are due to Dr. Dieter Cunz, a member of the University of Maryland faculty and student of German-American history, who arranged with Mr. Kroekel to make the gift.

From the city of Newark has been received a complete file-about eight hundred volumes, in good condition—of the Newark Evening Nerws. For the period from I 883 this is one of the most valuable papers for New Jersey historical research. In the past, as now, the Nerws coverage of political and other state events has been especially informative. Three volumes of the Passaic Herald, 1875/6, and Daily Neros, I 897, have been presented by the Passaic Herald-Neros office.

Four issues of Arnett's Nerw-Jersey Federalist, I 794-95, two of them incomplete, have been added to the Library's holdings. The 
Federalist is second in a series of consecutive newspapers published in New Brunswick between November I 793 and February I 796, contemporaneously with the better-known Guardian. Only about two dozen issues of the four component titles are known to have been preserved. Of the Federalist, seven dates are recorded, all of them in the Rutgers Library collection.

Two curious volumes of colored plates are among the recent book acquisitions, one of these a collection of the so-called suppressed caricatures of James Gillray. It is undated, but, like the two-volume Works of James Gillray published I 85 I by Henry G. Bohn (also in the Rutgers University Library), it undoubtedly was put out well after the artist's death. A perusal of these forty-five "suppressed" caricatures leaves one in no doubt as to why they might have been suppressed. Gillray, in his short life (I757-1816), mustered his satiric talents on one side or another of nearly every available controversy, attacking many highly-placed persons, including the King. His work was vigorous and intense, his satire usually sharp, often bitter, and sometimes (by present standards, at least) exceedingly coarse. His last known etching was done in $\mathrm{I} 8 \mathrm{I} \mathrm{I}$, as insanity closed down upon him.

A volume of anonymous caricatures entitled Horrida Bella; Pains and Penalties versus Truth and Justice (London, 1820) is part of the voluminous pamphlet literature relating to the case of Queen Caroline. This lady married the Prince of Wales in I795, and the two were soon estranged and separated. From that time on, the Prince (later King George IV) mistreated her in a variety of ways, being concerned eventually in charges of misconduct brought against her. Although her behavior on occasion had been at least ill-advised, the manifest persecution by the king and his supporters brought a great deal of popular support to the side of Caroline. The Horrida Bella consists of twenty-four well-executed etchings (colored) with accompanying text in verse, each headed by a letter of the alphabet. (" $A$, for an Archer [i.e., the King], who wounded a Queen ..."; etc.)

Other works of interest lately received: Goldsmith's Deserted Village (London, I770); James Thomson's Castle of Indolence (London, I748); Wordsworth's Peter Bell (London, I 8I9); James Macpherson's Temora (London, I763). An early edition (printed in Aberdeen, undated) of Matthew G. Lewis' novel of violence and 
the supernatural, The Monk, brings to mind the one-time popularity of this work. Lewis is nearly forgotten today, but when The Monk appeared in 1796 , he became famous at the age of twenty-one.

Adam's Luxury, and Eve's Cookery (London, I744) is the gift of Mr. Louis Silver, through Mr. I. Robert Kriendler '36. From Mr. William J. Myers ' 35 have been received first editions of Bret Harte, James Fenimore Cooper, Hemingway, and other American writers. Mrs. Maurice Rona has presented over fifty volumes on graphology.

In the area of manuscripts and broadsides, some fifty accessions have been recorded in the past six months. Although detailed listing is not possible, acknowledgment is made to the following donors: William H. Ruckle, Lawrence B. Romaine, Pierre D. Van Mater '20, Asher A. Howell, C. Rexford Davis '28, Miss Dorothy Oliver, Charles E. Feinberg, Hubert G. Schmidt, Ph.D., '45, Mrs. Bernart Chamberlain, Philip G. Nordell, Oliver K. Westling '33, Spencer Brodney, Joseph L. Naar, Jr.

Special note should be made, in brief, of a few manuscript accessions: Lewis D. Hardenbergh papers, I 9 items, I 749-1927, including letters of Dina (van Bergh) Hardenbergh; from Mr. Karl C. Ruppenthal. Elmer T. Hutchinson papers, 2 boxes, c. 1925-54, largely notes on Mormons, early taverns, etc., in New Jersey; from Mrs. Hutchinson. Franz M. Schneeweiss papers, I box, I 849-I 9 I 4, letters received, diary, etc., of an Austrian Forty-Eighter, later of New Brunswick; from Miss Catharine Schneeweiss. Joseph Warren Scott papers, 9 boxes, 2 vols., c. I 720-c. I 875, a New Brunswick lawyer's papers, gift of the Jersey Blue Chapter, D.A.R. Particularly valuable is the body of transcripts and other data assembled by Dr. Nelson R. Burr for his Anglican Church in New Jersey (1954). These include over two dozen albums in which are arranged photocopies of letters and journals of missionaries in colonial New Jersey, serving the Society for the Propagation of the Gospel in Foreign Parts. This fine body of research material is the gift of the Church Historical Society, through Canon Walter H. Stowe, historiographer of the Protestant Episcopal Church in America. 


\section{Exhibitions}

During the present year, literary Americans are celebrating the hundredth anniversary of Walt Whitman's Leaves of Grass. The marking of this event-little acclaimed in I 855-climaxes a century in which the figure of Whitman has grown to uncommon dimensions. Still on display at this writing, the Library's Whitman exhibit has attracted considerable interest-evidence of the poet's present-day popularity.

The exhibit combines with a selection of facsimile views and autograph material, obtained from the Library of Congress, a number of original items from the Rutgers University Library's own collection. Among the latter are nine autograph letters, I 865-9I, bearing on such matters as the poet's declining health, his literary philosophy, the celebration of his birthday. Included too are the correspondence and writings of William Sloane Kennedy in relation to Whitman's alleged unpaid debt to James Parton. Kennedy, long a champion and biographer of Whitman, hoping to disprove the report, gathered evidence from every hand-not, however, altogether conclusive. Involved in the controversy was Thomas Wentworth Higginson who - to express the condition mildly_did not share Kennedy's admiration for Whitman, man or poet.

Following the poet's death in I 892, Kennedy was especially irked to find an extended literary-biographical notice of Whitman published in the New York Evening Post-authored by Colonel Higginson. While the article is well enough written and gives some evidence of a wish to treat the dead Whitman fairly, it is anything but a complimentary one. Kennedy's own clipping of the item, on display in the present exhibit, bears his note: "the estimate of a great soul by a mean $\&$ small one who belongs to the critical fry, \& has himself failed in great creation." He later wrote an article detailing the whole story of Higginson's critical assaults on Whitman, calling it "Euphrasy and Rue for T. W. Higginson." That too is on display, a manuscript of fourteen leaves- "Not written for publication during the present generation, or the next."

The Whitman letters, the Parton-debt correspondence, and the original draft of his poem, "Hush'd be the Camp To-day," have been described in earlier issues of the Journal. Among the other items 
exhibited are portions of Whitman's writings on various subjects. One of these, a two-page manuscript, deplores the imitation of foreign writers and calls for an American literature. "Ye have feebly followed \& feebly multiplied the models of other lands. I come to call you to the knowledge of the Living God in writing . . . Know ye, ye may have all other possessions but without your own soul's Literature, ye are but little better than trading, prosperous beasts. Aping but others, ye are but intelligent apes ... Its Literature, when it comes, is to be the most serious, most subtle, most solid part of America, \& making its conflicting elements homogeneous \& the States a Nation ..."

D.A.S. 